\title{
Evaluation of the Cyto-protective Effects of Erythropoietin on Contrast Induced Nephropathy in Rats
}

\author{
Moshira A. Rateb* and Maie M. Ismaiel** \\ * Physiology Department, Faculty of Medicine, Cairo University \\ ** Radiology Department, Helwan University Hospital
}

\begin{abstract}
Erythropoietin has long been used in renal failure patients for its hematopoeitic properties. It has recently been claimed to possess cytoprotective effects on many other cell lines including renal tubular cells. The aim of the present study was to assess the possible effects of erythropoietin on prevention of contrast induced renal failure in male rats. Methods: Thirty-two male albino rats were divided into four groups ( $n=8$ each): control $(C)$, contrast media $(C M)$, erythropoietin (E) and rats treated with one single dose erythropoietin (4000 IU/Kg) IP 30 minutes before IV injection of the high osmolar contrast media diatrizoate $(6 \mathrm{ml} / \mathrm{kg})(E+C M)$. All the groups were subjected to dehydration for 72 hours before any injections were done. Hematological indices, kidney function parameters, oxidative stress markers, tumor necrosis factor alpha as a marker for inflammation and caspase 3 activity as a marker for apoptosis were measured after 72 hours of injections. Results: Injection of diatrizoate in dehydrated animals resulted in reduction of GFR, increased blood urea nitrogen and serum creatinine. It was associated with increased TNFa release and increased activation of caspase 3 as well as increased oxidative stress in kidney homogenates. Erythropoietin injection prior to the injection of the contrast medium significantly improved renal function parameters and was associated with a reduction in TNF alpha production, a reduction of caspase 3 activity and an increase in superoxide dismutase activity in the kidneys. Conclusion: Erythropoietin can infer protective effects to the kidneys against contrast induced nephropathy through mechanisms that are independent of its effect on the red cell mass.
\end{abstract}

Key words: Erythropoietin, contrast medium, renal failure, oxidative stress, apoptosis.

\section{INTRODUCTION}

Contrast-induced nephropathy (CIN) is most commonly defined as acute renal failure occurring within 48 hours of exposure to intravascular radiographic contrast material that is not attributable to other causes ${ }^{(\mathbf{1})}$. Contrast-induced nephropathy usually manifests as a non-oliguric and asymptomatic transient decline in renal function ${ }^{(2)}$. The serum creatinine level begins to rise within 24 hours of contrast administration, usually peaks within 3-5 days, and returns to baseline within 10-14 days causing an increased medical and economic burden to both the patient and the health system ${ }^{(3)}$ 
The exact underlying mechanisms of contrast media induced nephrotoxicity have yet to be fully elucidated but are likely to involve the interplay of reduction in renal perfusion and increased renal tubular oxidative stress with, dehydration and decreased effective intravascular volume leading to exaggeration of the direct toxic effects of the contrast medium $^{(4)}$

Several strategies have been used in order to reduce the occurrence of such a complication including proper evaluation of high risk patients who are more likely to suffer from CIN, choice of contrast media to be used and the dose used, proper hydration, stoppage of nephrotoxic drugs before injection of the contrast and the use of some protective agents such as $\mathrm{N}$ acetyl cysteine and adenosine antagonists. ${ }^{(5)}$

Erythropoietin hormone has been recently suggested as a possible cytoprotective agent in many cell lines. Erythropoietin receptor (Epo-R) expression was described in various cell lines such $\mathrm{t}$ as endothelial cells, neuronal cells, cardiac myocytes, and vascular smooth muscle cells ${ }^{(6)}$. It is believed that erythropoietin can play a protective role in such tissues both directly by activating multiple biochemical mechanisms that provide antiapoptotic, antioxidative, and antiinflammatory response to hypoxia/anoxia and indirectly via its angiogenic potential by inducing oxygen systematic supply to the ischemic tissue ${ }^{(7)}$

In the nervous system, Ehrenreich et al (8) found an improvement in cognitive properties in schizophrenia patients after erythropoietin treatment
(40.000 IU twice weekly for twelve weeks) confirming a neuroprotective role for the hormone.

In the cardiovascular system however, erythropoietin has shown controversial results. It was reported that the hormone can mediate cardioprotection against acute ischemic injury through inhibition of apoptosis and reducing the incidence of cardiac failure that frequently complicates such events ${ }^{(\boldsymbol{9}, 10)}$. However, recent evidence from randomized trials showed an increased risk of cardiovascular events and increased mortality in patients with chronic heart failure receiving erythropoietin treatment ${ }^{(11)}$.

In the renal system, Yang et al. (12) have described a protective effect of erythropoietin on renal tubular functions after ischemia reperfusion injury through induction of heat shock protein 70 and increasing the expression $\mathrm{n}$ of c-jun NH2-terminal kinase $(\mathrm{JNK})$ and reduction of caspase 3 activity.

The aim of the present study was to investigate the possible cytoprotective effects of erythropoietin on the kidney functions in acute contrast induced renal failure in male rats through examining its effects on the activity of the pro-apoptotic enzyme (caspase 3) and on the oxidant/antioxidant state in kidney homogenates as well as evaluating renal functions and inflammatory markers in the blood of the studied groups.

\section{MATERIALS \& METHODS}

\section{Experimental animals:}

This study involved 32 male albino rats weighing between 170 and 
200 g. The animals were randomly divided into four groups each consisting of 8 rats. Animals were fed a standard diet and housed in the animal house of Kasr Al-Aini Faculty of Medicine with a 12:12-h light/dark cycle._The study protocol lasted for six days and was approved by the faculty ethical committee for research

\section{Induction of contrast induced renal failure}

We have followed the method suggested by Topraki et $\mathrm{al}^{\text {( }}{ }^{\text {13) }}$ to produce contrast induced renal failure. They found that a preliminary period of 72 hours (hrs) of water deprivation followed by intravenous (IV) injection of diatrizoate (Urografin) $(6 \mathrm{ml} / \mathrm{kg})$ resulted in tubular necrosis, tubular protein casts, medullary congestion and impaired renal functions. Therefore, CIN was induced by diatrizoate $(6 \mathrm{ml} / \mathrm{kg})$, after a 72 hrs.dehydration period.

The animals were allowed free access to food during the first three days of the protocol but were restrained from receiving any water. After the injections of the used drugs were made, the animals were returned to their cages and allowed free access to water and standard diet for another 72 hours before measurements were made.

Injections were done at same time of day for all groups.

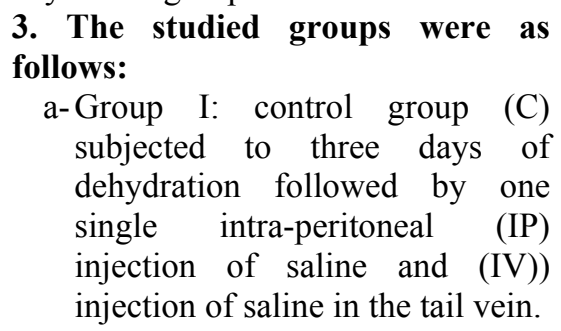

b-Group II: Erythropoietin group (E) subjected to three days of dehydration followed by one single (IP) injection of 4000 IU/kg Erythropoietin.

c-Group III: contrast media (CM): animals subjected to three days of dehydration followed by (IV) injection of contrast at dose of $6 \mathrm{ml} / \mathrm{kg}^{(13)}$

d-Group IV: contrast media + Erythropoietin $(\mathrm{CM}+\mathrm{E})$ : animals subjected to three days of dehydration followed by (IP) injection of $(\mathrm{E})$ at the dose of $4000 \mathrm{IU} / \mathrm{Kg}$ followed 30 minutes later by IV injection of contrast medium. $^{(14)}$

Erythropoietin was obtained as Eprex syringes (alpha erythropoietin 2000IU/ml) from Cilag while diatriozoate was obtained as Urografin $(20 \mathrm{ml})$ ampoules $76 \%$ Schering AG, Germany .

\section{Parameters measured:}

72 hours after injections were given, the following measurements were performed:

\subsection{Blood and serum parameters}

4.1.1.Blood indices and renal function parameters

Blood samples were procured for measurements of hematocrit value and red cell count, blood urea nitrogen (BUN) and serum creatinine from the caudal vein. Creatinine $(\mathrm{Cr})$ measurements were performed using the Rate-Blanked creatinine/Jaffe method on a Roche/Hitachi autoanalyser $^{(\mathbf{1 5})}$.

BUN measurements were performed using the method of Patton and Crouch $^{(\mathbf{1 6})}$ on a Roche/Hitachi autoanalyser. Hematological 
measurements were performed on a Baker 9000 hematology analyzer.

4.1.2 Measurement of serum tumor necrosis factor alpha (TNF- $\alpha)$

Serum TNF- levels were measured by ELISA according to the manufacturer's instructions (Biosource, USA) according to the principle of Mizutani et al. ${ }^{(17)}$

4.2. Glomerular filtration rate (GFR) assessment

After primary collection of blood samples from caudal veins, the GFR was assessed. We used the method described by Efrati et al. ${ }^{(\mathbf{1 8})}$ using ${ }^{99}$ mTechnetium diethylene triaminepentaacetic acid $\left({ }^{99 m} \mathrm{Tc}\right.$ DTPA) injection. $0.1 \mathrm{ml}$ of $1 \mathrm{uCi} / \mathrm{ml}$ ${ }^{99 m}$ Tc-DTPA was injected intraperitoneally which was followed 60 minutes later by obtaining $50 \mathrm{ul}$ blood sample from the caudal vein and diluting it in $2 \mathrm{ml}$ of phosphatebuffered saline ( $\mathrm{pH}$ 7.4). Standard solution was prepared from $0.1 \mathrm{ml}$ of $1 \mathrm{mCi} / \mathrm{ml}^{99 \mathrm{~m}}$ Tc-DTPA stock solution. Radioactivity of the samples was measured in a gamma counter (LKB, USA) and GFR values were calculated using the following formula:

$\mathrm{GFR}=\mathrm{V} \times \mathrm{Ln}(\mathrm{CPM} 0 / \mathrm{CPMt}) / \mathrm{t}$ where $\mathrm{V}$ is the volume of distribution ( 0.3 of animal weight in $\mathrm{mg}$ ); (CPM0) is the radioactivity counts per min of standard solution; (CPMt) is the radioactivity counts per minute, 60 minutes after ${ }^{99} \mathrm{mTc}-\mathrm{DTPA}$ injection; and $(\mathrm{t})$ is the time $(\mathrm{min})$ between the ${ }^{99}$ mTc-DTPA injection and the blood sample procurement ${ }^{(\mathbf{1 8})}$

\subsection{Measurements in tissue homogenates}

After measurements were performed for GFR, the rats were lightly anaesthetized by sevoflurane inhalation and then sacrificed by cervical dislocation. The kidneys were quickly exposed and isolated, washed with saline, dried on blotted paper and weighed. Homogenates of the right kidney in Phosptate extraction buffer solution $(10 \% \mathrm{~W} / \mathrm{V})$ were obtained using Branson sonifier and were used for assay of caspase-3 activity as a marker for tissue apoptosis. The homogenates of left kidney_were used for determination of the oxidant/antioxidant state of kidney by evaluation of malondialdehyde production as an index of lipid peroxidation and total superoxide dismutase activity (SOD) activity.

4.3.1. Measurement of Malondialdehyde (MDA):

MDA was measured in tissue homogenates after precipitation of protein by addition of trichloroacetic acid then thiobarbituric acid (TBA). TBA reacted with MDA to form TBA reactive product, which was measured at $532 \mathrm{~nm}{ }^{(19)}$. Results were expressed as $\mathrm{nmol} / \mathrm{gm}$ tissue.

4.3.2. Determination of Superoxide dismutase (SOD) activity

The SOD activity was determined by a modified version of the method of Minami and Yoshikawa (20). .Fifty microliters of the kidney homogenate was mixed with

$450 \mu \mathrm{L}$ of cold deionized water, 125 $\mu \mathrm{L}$ of chloroform, and $250 \mu \mathrm{L}$ of ethanol. The mixture was centrifuged at $8000 \mathrm{~g}$ for 2 minutes at $4 \circ \mathrm{C}$. Five hundred microliters of the extract was added to the reaction mixture containing $500 \mu \mathrm{L}$ of $72.4 \mathrm{mM}$ triscacodylate buffer with $3.5 \mathrm{mM}$ diethylene pentaacetic acid ( $\mathrm{pH} 8.2)$, $100 \mu \mathrm{L}$ of $16 \%$ TritonX-100, and 250 
$\mu \mathrm{L}$ of $0.9 \mathrm{mM}$ nitroblue tetrazolium (NBT). The reaction mixture was incubated for 5 minutes at $37{ }^{\circ} \mathrm{C}$ before adding $10 \mu \mathrm{L}$ of $9 \mathrm{mM}$ pyrogallol (dissolved in 10mMHCL). Then, it was incubated for exactly 5 minutes at $37 \circ \mathrm{C}$. The reaction was stopped with the addition of $300 \mu \mathrm{L}$ of $2 \mathrm{M}$ formic buffer ( $\mathrm{pH} 3.5$ ) containing $16 \%$ TritonX-100. The absorbance was measured at $540 \mathrm{~nm}$ in the spectrophotometer. One unit of SOD enzymatic activity is equal to the amount of enzyme that diminishes the initial absorbance of nitroblue tetrazolium by $50 \%$.

\subsubsection{Caspase 3 Activity}

$30 \mathrm{mg}$ of fresh kidney tissue was homogenized in extraction buffer and centrifuged and $10.000 \mathrm{rpm}$ for 15 $\min$, at $4^{\circ} \mathrm{C}$. The supernatant was stored at $-80^{\circ} \mathrm{C}$ for one month for Caspase 3 activity immunoassay (Quantikin R and D systems, Minneapolis, USA) following the manufacturer's instructions and expressed per microgram of protein.

\section{Statistics}

Results are expressed as mean \pm SD. Groups were compared using unpaired student's t-test or by one way ANOVA with Post hoc for analysis for statistical significance between groups. A p-value $\leq 0.05$ was considered significant.

\section{RESULTS}

\section{Blood and serum parameters}

Blood samples taken 72 hours after injections showed no statistically significant difference between any of the groups studied as regards the hematocrit (control $=43.02 \pm 1.3 \%, \quad \mathrm{E}=44.1 \pm 1.5 \%$, $\mathrm{CM}=45.03 \pm 1.7 \%, \mathrm{CM}+\mathrm{E}=43.4 \pm 1.3)$.

(Fig 1) or the red cell count (in $10^{6} / \mu \mathrm{l}$ ) $(\mathrm{C}=6.23 \pm 0.41, \mathrm{E}=\quad 6.45 \pm 0.89$, $\mathrm{CM}=6.38 \pm 0.9, \mathrm{CM}+\mathrm{E}=6.3 \pm 0.5)$. Fig (2)

However, kidney function tests show significant increase in BUN and serum creatinine in samples from animals receiving contrast media when compared to control group $(\mathrm{P} \leq 0.05)$ or to erythropoietin group $(\mathrm{P} \leq 0.05)$. The injection of erythropoietin prior to the injection of the contrast medium led to a significant reduction of the levels of BUN and creatinine measured when compared to the contrast medium group $(\mathrm{P} \leq 0.05)$, however, these values were still significantly higher than the control values $(\mathrm{P} \leq 0.05)$. Erythropoietin injection in group II (E group) did not result in any significant change in BUN and creatinine measured 72 hours after injection when compared to control group.

Erythropoietin significantly reduced TNF- $\alpha$ in group II when compared to control $(\mathrm{P} \leq 0.05)$. Injection of contrast medium in group III resulted in a significant increase in TNF- $\alpha$ levels when compared to group I control group. $(\mathrm{P} \leq 0.05)$.

Erythropoietin injection before to the injection of the contrast medium resulted in a significant reduction in TNF- $\alpha$ when compared to group III (.(P $\leq 0.05)$, however, the level was still significantly higher than those encountered in control group I. $(\mathrm{P} \leq 0.05)$. (Table 1)

\section{Glomerular filtration rate}

Measurements of GFR confirmed the previous results of renal functions in different studied groups as 
erythropoietin in group II did not show any significant change in values of GFR when compared to control group $\quad(1.56 \pm 0.2 \mathrm{ml} / \mathrm{min} \quad$ versus $1.6 \pm 0.3 \mathrm{ml} / \mathrm{min}, \mathrm{P} \geq 0.05$ ).

The injection of contrast medium resulted in a significant reduction in GFR when compared to control group $(0.42 \pm 0.18 \quad \mathrm{ml} / \mathrm{min}$ versus $1.6 \pm 0.3 \mathrm{ml} / \mathrm{min} . \mathrm{P} \leq 0.05)$. The injection of erythropoietin prior to the injection of the contrast medium resulted in a significant improvement of GFR when compared to group III contrast medium $\quad(0.93 \pm 0.22 \mathrm{ml} / \mathrm{min}$ versus $0.42 \pm 0.18 \mathrm{ml} / \mathrm{min}$. $\mathrm{P} \leq 0.05$, however such values in group IV were still significantly less than values obtained in group I control group. $(0.93 \pm 0.22 \mathrm{ml} / \mathrm{min}$

versus $1.6 \pm 0.3 \mathrm{ml} / \mathrm{min} . \mathrm{P} \leq 0.05$ ) Fig (3).

3. Evaluation of apopotosis by Caspase 3 activity in kidney homogenates

Our results show that a single erythropoietin injection resulted in a significant reduction in caspase 3 activity when compared to group I. $(\mathrm{P} \leq 0.05)$. Injection of Urografin $(6 \mathrm{ml} / \mathrm{kg})$ resulted in a significant increase in the activity of caspase 3 from kidney homogenates when compared to group I. $(\mathrm{P} \leq 0.05)$
Injection of Erythropoietin prior to the injection of Urografin resulted in a significant reduction in the activity of caspase 3 when compared to group III $(\mathrm{P} \leq 0.05)$. The activity of caspase 3 in group IV almost returned to levels encountered in group I. ( $\mathrm{P} \geq 0.05$ ) Table (2).

4. Evaluation of Superoxide dismutase activity (SOD) and Malondialdehyde content (MDA) in kidney homogenates.

Our results show that erythropoietin injection in group II did not result in a significant change in SOD activity or MDA content when compared to group I. $(\mathrm{P} \geq 0.05)$. Injection of Urografin resulted in a significant reduction of SOD activity $(\mathrm{P} \leq 0.05)$ and increased MDA content $(\mathrm{P} \leq 0.05)$ when compared to group $\mathrm{I}$. The injection of Erythropoietin before the injection of Urografin resulted in a significant increase in SOD activity when compared to group III ( $\mathrm{P} \leq 0.05)$ and significant reduction in MDA content. $(\mathrm{P} \leq 0.05)$ when compared to group III, however, MDA levels were still significantly higher than levels obtained in control group I. ( $\mathrm{P} \leq 0.05)$. (Table 2). 
Fig. (1): Effect of erythropoietin, contrast media, and erythropoietin + contrast media injection on Hematocrit percentage $(\mathrm{Ht} \%)$ in different groups of rats involved in the study 72 hours after injections were administered.

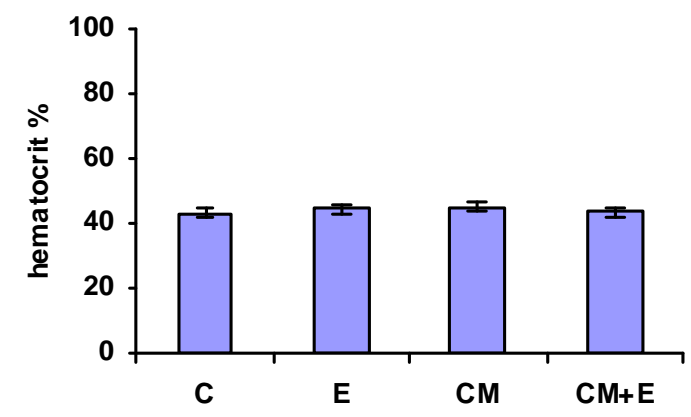

$\mathrm{C}=$ control group, $\mathrm{E}=$ Erythropoietin group, $\mathrm{CM}=$ contrast media group, $\mathrm{CM}+$ $\mathrm{E}=$ contrast media + erythropoietin group. Results are expressed as means \pm S.D. No statistical difference exists between the studied groups.

Fig. (2): Effect of erythropoietin, contrast media, and erythropoietin + contrast media injection on red cell count (RCC) in different groups of rats involved in the study 72 hours after injections were administered

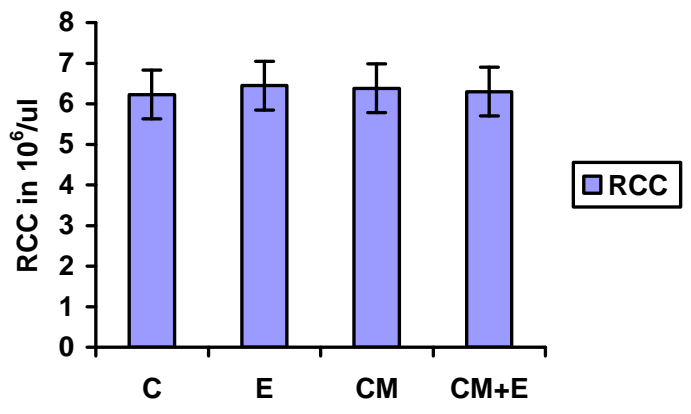

$\mathrm{C}=$ control group, $\mathrm{E}=$ Erythropoietin group, $\mathrm{CM}=$ contrast media group, $\mathrm{CM}+$ $\mathrm{E}=$ contrast media + erythropoietin group, $\mathrm{RCC}=$ Red cell count in $10^{6} / \mu \mathrm{l}$. Results are expressed as means \pm S.D.

No statistical difference is present between groups. 
Fig. (3): Effect of erythropoietin, contrast media, and erythropoietin + contrast media injection on glomerular filtration rate (GFR) in $\mathrm{ml} /$ minute in the different groups of rats involved in the study 72 hours after injections were administered.

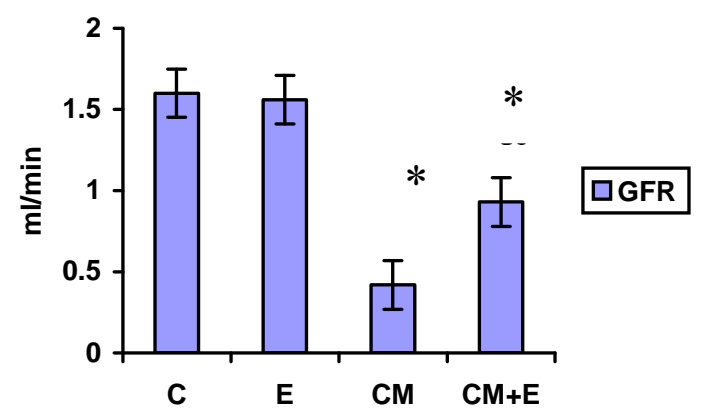

$\mathrm{C}=$ control group, $\mathrm{E}=$ Erythropoietin group, $\mathrm{CM}=$ contrast media group, $\mathrm{CM}+$

$\mathrm{E}=$ contrast media + erythropoietin group. Results are expressed as means \pm S.D. * Significant changes in comparison to control group I. ( $\mathrm{P} \leq 0.05)$.

** Significant changes in comparison to contrast media Group III. $(\mathrm{P} \leq 0.05)$

The figure shows a beneficiary effect on GFR when erythropoietin was injected (IP) prior to administration to contrast medium by (IV) route.

Table (1): Effect of erythropoietin (4000IU/kg) (IP) injection, Contrast medium $(6 \mathrm{ml} / \mathrm{kg})(\mathrm{IV})$ or erythropoietin followed 30 minutes later by injection of the contrast medium on Blood urea nitrogen $(\mathrm{mg} / \mathrm{dl})$, serum creatinine $(\mathrm{mg} / \mathrm{dl})$ and TNF- $\alpha(\mathrm{pg} / \mathrm{ml})$ in the different studied groups as measured 72 hours after injections.

\begin{tabular}{llll}
\hline Group & BUN (mg/dl & Cr $(\mathbf{m g} / \mathbf{d l})$ & TNF- $\alpha(\mathbf{p g} / \mathbf{m l})$ \\
\hline $\mathrm{C}$ & $20.32+0.73$ & $0.42+0.02$ & $7+3.2$ \\
\hline $\mathrm{E}$ & $21.05+0.43$ & $0.43+0.01$ & $3.2+1.5^{*}$ \\
\hline $\mathrm{CM}$ & $70.3+2.6^{*}$ & $1.07+0.03^{*}$ & $42.1+10.2^{*}$ \\
\hline $\mathrm{CM}+\mathrm{E}$ & $34.32+0.32^{* ¥}$ & $0.73+0.05^{* ¥}$ & $23.4+6.3^{* *}$ \\
\hline
\end{tabular}

Results are mean \pm SD.

$\mathrm{C}=$ control, $\mathrm{E}=$ Erythropoietin (4000IR $/ \mathrm{Kg}$ ip), $\mathrm{CM}=$ contrast medium $(6 \mathrm{ml} / \mathrm{kg} \mathrm{IV})$, $\mathrm{CM}+\mathrm{E}=$ contrast medium + Erythropoietin. $\mathrm{BUN}=$ blood urea nitrogen, $\mathrm{Cr}=\mathrm{Serum}$ creatinine, $\mathrm{TNF} \alpha=$ tumor necrosis factor alpha.

* significant change in comparison to control group I. $\mathrm{P} \leq 0.05$.

$¥$ significant change in comparison to $\mathrm{CM}$ group III. $\mathrm{P} \leq 0.05$. 
Table (2): Effect of erythropoietin (4000IU/kg) (IP) injection, Urografin $(6 \mathrm{ml} / \mathrm{kg}$ ) (IV) or erythropoietin followed 30 minutes later by injection of the contrast medium on Caspase 3 activity (ng/ug protein), superoxide dismutase activity (IU/ug protein) and Malondialdehyde(nmol/g tissue) in the different studied groups at 72 hours after injection time.

\begin{tabular}{llll}
\hline Group & $\begin{array}{l}\text { Caspase 3 } \\
\text { (ng/ug protein) }\end{array}$ & $\begin{array}{l}\text { SOD } \\
\text { (IU/ug protein) }\end{array}$ & $\begin{array}{l}\text { MDA } \\
\text { nmol/g tissue }\end{array}$ \\
\hline $\mathrm{C}$ & $15.2+1.2$ & $3.46+0.4$ & $102.4+5.3$ \\
\hline $\mathrm{E}$ & $11.3+0.5^{*}$ & $3.52+0.8$ & $100.3+4.4$ \\
\hline $\mathrm{CM}$ & $22.3+2.6^{*}$ & $1.7+0.14^{*}$ & $153.6+9.6^{*}$ \\
\hline $\mathrm{CM}+\mathrm{E}$ & $15.9+1.6^{¥}$ & $3.15+0.28^{¥}$ & $124.3+7.8^{*}$ \\
\hline
\end{tabular}

Results are mean $\pm \mathrm{SD}$.

$\mathrm{C}=$ control, $\mathrm{E}=$ Erythropoietin (4000IR $/ \mathrm{Kg}$ ip), $\mathrm{CM}=$ contrast medium $(6 \mathrm{ml} / \mathrm{kg} \mathrm{IV})$, $\mathrm{CM}+\mathrm{E}=$ contrast medium + Erythropoietin. $\mathrm{SOD}=$ Superoxide dismutase ,

$\mathrm{MDA}=$ Malondialdehyde

* significant change in comparison to control group I. $\mathrm{P} \leq 0.05$.

$¥$ significant change in comparison to $\mathrm{CM}$ group III. $\mathrm{P} \leq 0.05$.

\section{DISCUSSION}

Our results show that injection of the high osmolar contrast medium diatrizoate had no effect on the hematocrit value or the red blood cell count in the studied animals when compared to control group. However, the animals showed a significant reduction in GFR, a significant increase in BUN and serum creatinine.

Thormoson and Morcos ${ }^{(21)}$ suggest that particles of contrast material exert an osmotic force causing marked reduction of reabsorption of water and sodium from the tubules. Contrast medium induced natriuresis leads to stimulation of tubuloglomerular feedback (TGF) mechanism which will cause a reflex vasoconstriction of the afferent arterioles and reduction in the glomerular filtration rate (GFR) with subsequent changes in serum creatinine and blood urea nitrogen.

Our results suggest that the injection of contrast medium leads to some form of systemic inflammatory response as manifested by increased release of tumor necrosis factor alpha as well as increased local production of superoxide radicals and activation of kidney apoptosis as manifested by increased kidney content of MDA an activation of caspase 3 enzyme. In addition, a direct toxic effect is also manifested as reduction of superoxide dismutase activity suggesting a decreased ability of the cell to fight against oxidative stress.

Topraki et al. ${ }^{(\mathbf{1 3})}$ also reported increased systemic and kidney oxidative stress following diatrizoate while Yano et al ${ }^{\text {(22) }}$ and Tervahartiala et $\mathrm{al}^{(\mathbf{2 3})}$ similarly reported the induction of apoptosis and activation 
of caspase enzymes by radicontrast media in tubular cells.

Erythropoietin injection in groups II did not result in any significant change in red cell count or hematocrit percent measured 72 hours after injection when compared to control group.

Egrie et al ${ }^{(24)}$ have previously reported that recombinant erythropoietin does not show species boundary and its primary role involves prevention of programmed cell death (apoptosis) of erythrocyte precursors. Erythropoietin induces erythropoiesis by promoting proliferation and differentiation of erythroid progenitor cells with the main target cell being the colonyforming unit erythroid (CFU-E) ${ }^{(\mathbf{2 5})}$.

However, such effect requires few weeks to appear in the circulation (26) and it is thus possible to rule out that any beneficial effect that might be encountered in our study is caused by improved tissue oxygenation due to increased red corpuscle mass and blood oxygen carrying capacity.

The injection of erythropoietin before the injection of the contrast medium resulted in a significant improvement in the GFR in group IV when compared to group III (CM).

Mitra et al. ${ }^{(14)}$ suggest that while erythropoietin might not change renal blood flow, it might still affect GFR through a direct effect on glomerular membrane permeability or a counterbalancing decrease in glomerular afferent and increase in glomerular efferent arteriole resistance.

Ruschitzka et al. ${ }^{(27)}$ also suggested that erythropoietin can play a protective role in the cardiovascular system through increased endothelial nitric oxide synthetase (eNOS) expression, increased nitric oxide (NO) production, and NO-mediated vascular relaxation. This mechanism could possibly contribute to the regulation of the afferent arterioles in the glomeruli and help improve the GFR after contrast injection.

Erythropoietin injection before the injection of the contrast medium resulted in a significant reduction of caspase 3 activity in group IV returning the levels almost to those encountered in the control group

Jacobs et al. (28) explained that when a single molecule of erythropoietin binds its receptor, it activates JAK2, which in turn activates NF-kB resulting in increased expression of apoptosis inhibiting genes, such as XIAP and c-IAP2. Erythropoietin also inhibits various metabolic paths that are connected to cell death, such as those which are related to glycogen synthetase kinase $3 \beta$ (GSK3 $\beta$ ), Bcl-2 associated death promoting protein (BAD), caspase-9, etc

Yukiyo et al. ${ }^{(29)}$ also reported an increased expression of the protective heat shock protein 70 (HSP 70) in renal tubular cells one hour after injection of erythropoietin and suggested this increase can play an important role in the prevention of contrast medium-induced renal tubular cell apoptosis.

Erythropoietin injection prior to the injection of the contrast medium resulted in a significant reduction of systemic TNF- $\alpha$ when compared to group III receiving contrast medium alone. 
Csiszar et al. ${ }^{(30)}$ have demonstrated that TNF- can induce oxidative stress by upregulating/activating NADPH oxidase, endothelial dysfunction, endothelial apoptosis, and up-regulation of proatherogenic inflammatory mediators, such as inducible nitricoxide synthetase (iNOS) and adhesion molecules.

In the liver, Jaeschke et al. ${ }^{(31)}$ implicated TNF- $\alpha$ but not IL- $1 \alpha \beta$ in increased caspase activity and apoptosis and indicated that activation of the caspase 3 subfamily of cysteine proteases is critical for the development of parenchymal cell apoptosis. In addition, they have pointed that excessive hepatocellular apoptosis can be an important signal for transmigration of primed neutrophils sequestered in sinusoids promoting further necrosis of parenchymal cells.

The demonstrated ability of erythropoietin in reducing TNF alpha production can therefore be expected to play an important role in preventing many of the cascading events that finally result in contrast induced nephropathy.

Erythropoietin also resulted in a significant increase in superoxide dismutase activity, a finding which was also reported by Mitra et al. ${ }^{\text {(14) }}$ in their assessment of the effect of erythropoietin on renal functions during endotoxamia.

The oxidative state of a tissue is determined by the balance between the oxidative and antioxidative systems. Inside the kidney, such balance is maintained by the activities of oxidant enzymes such xanthine oxidase and NADH and NADPH- dependent oxidases and the activities of anti-oxidant enzymes such as superoxide dismutase, catalase and glutathione peroxidase ${ }^{(32)}$.

Erythropoietin reduction of TNF alpha is expected to result in a reduction of oxidative enzymes activation $^{(30)}$ which in addition to increased activation of the antioxidative enzyme activities can explain the reduction of lipid peroxidation and decreased MDA content that we reported in our experiment.

In conclusion, we have demonstrated that one single injection of erythropoietin can provide a degree of renal protection against contrast induced nephropathy. Erythropoietin might modulate its effect on the renal tubular cells though a sequence of events that prevent excessive tubular injury by reducing TNF alpha production which in turn would reduce activation of caspase 3 and reduction of apoptosis. Reduction of apoptosis reduces the signal for neutrophil transmigration and sequestration and offers protection for renal tubular cells against further necrosis. This effect of erythropoietin seems independent of its ability to improve oxygenation through increasing red cell mass.

However, such novel effects of erythropoietin require further investigation to elucidate its biomolecular mediators and their applications in the high risk patients undergoing radio-contrast imaging.

\section{REFERENCES}

1. Barrett BJ, Parfrey PS. Prevention of nephrotoxicity 
induced by radiocontrast agents. N Engl J Med1994; 331:1449 1450.

2. Anderson RJ, Linas SL, Berns AS, et al. Nonoliguric acute renal failure. N Engl J Med1977; 296:1134-1138.

3. Berns J, Rudnick $M$. Radiocontrast media associated nephrotoxicity. Kidney 1992; $24: 1-5$

4. Gleeson T. and Bulugahapitiya S. Contrast-Induced Nephropathy. AJR 2004; 183:1673-1689.

5. Papendorf D. Radiocontrast nephropathy: Renal protection. SAJAA 2007;13(6) Nov/Dec: 2631.

6. Jelkmann W, Wagner $K$. Beneficial and ominous aspects of the pleiotropic action of erythropoietin. Ann Hematol. 2004;83:673-86.

7. Paschos N., Lykissas M., and Beris A.. The Role of Erythropoietin as an Inhibitor of Tissue Ischemia. Int $\mathrm{J}$ Biol Sci. 2008; 4(3): 161-168.

8. EhrenreichH, Hinze-SelchD, Stawicki S. et al. Amelioration of Cognitive Loss in Chronic Schizophrenia . J Am Soc Nephrol 2007;18: 3-6.

9. Saraste A, Pulkki K, Kallajoki M. et al. Apoptosis in human acute myocardial infarction. Circulation. 1997;95:320-3.

10. Olivetti G, Abbi R, Quaini F. et al. Apoptosis in the failing human heart. N Engl J Med. 1997;336:1131-41.

11. Drüeke TB, Locatelli F, Clyne N. et al. Normalization of hemoglobin level in patients with chronic kidney disease and anemia. N Engl J Med. 2006;355:2071-84.

12. Yang $C$, Li $C$, Jung J. et al. Preconditioning with erythropoietin protects against subsequent ischemia-reperfusion injury in rat kidney.FASEB.2003; 17 (12): 1754-55.

13. Topraki O, Cirit M, Tanrisev1 M. et al. Preventive effect of nebivolol on contrast-induced nephropathy in rats. Nephrol Dial Transplant 2008 ;23: 853859.

14. Mitra A, Bansal S, Wang W. et al. Erythropoietin ameliorates renal dysfunction during endotoxaemia. Nephrol Dial Transplant 2007; 22: 2349-2353.

15. Tietz, NW. Fundamentals of clinical chemistry, 1987; (3rd edition, p. 68), W.B. Saunders Company.

16. Patton, CJ and Crouch SR. Spectro-photometric and kinetic investigation of the Berthelot reaction for the determination of ammonia. Anal. Chem.1977; 49 (3): 464.

17. Mizutani A, Okajima $K$, Uchiba $M$ et al. Anti-thrombin reduces ischemia reperfusion induced renal injury in rats by inhibiting leucocyte activation through promotion of protacyclin production. Hemostasis, thrombosis and vascular biology 2003; 101 (6): 3029-36.

18. Efrati S, Averbukh M, Berman $\mathbf{S}$ et al. N-Acetylcysteine ameliorates lithium-induced renal failure in rats. Nephrol Dial Transplant 2005; 20: 65-70.

19. Draper H, and Hadley $M$. Assessment of malondialdehyde 
method. Enzymology 1991; 186: 421-443.

20. Minami M, Yoshikawa H. A simplified assay method of superoxide dismutase activity for clinical use. Clin Chim Acta. 1979;92(3):337-342.

21. Thomsen $H$. and Morcos S. British Contrast media and the kidney: European Society of Urogenital Radiology (ESUR) Guidelines Journal of Radiology 2003; 76: 513-518

22. Yano $T$, Itoh $Y$, Sendo $T$ et al.: Cyclic AMP reverses radiocontrast media-induced apoptosis in LLC-PK1 cells by activating A kinase/PI3 kinase. Kidney Int 2003; 64: 2052-2063.

23. Tervahartiala $P$, Kivisaari $L$, Kivisaari $\mathbf{R}$ et al. Structural changes in the renal proximal tubular cells induced by iodinated contrast media. Nephron 1977; 76: 96-102.

24. Egrie JC, Strickland TW, Lane $\mathbf{J}$ et al. Characterization and biological effects of recombinant human erythropoietin. Immunobiology. 1986;172:213224.

25. Fisher JW, Koury S, Ducey T. et al. Erythropoietin (Epo) production by interstitial cells of hypoxic monkey kidneys. $\mathrm{Br} \mathrm{J}$ Haematol. 1996;95:27-32.

26. Stein RS, Abels RI, Krants SB. Pharmacological doses of recombinanthuman erythropoietin in the treatment of myelodysplastic syndromes. Blood. 1991; 75:1658-1663.
27. Ruschitzka FT, Wenger RH, Stallmach T. et al. Nitric oxide prevents cardiovascular disease and determines survival in polyglobulic mice overexpressing erythropoietin. Proc Natl Acad Sci U S A. 2000; 97:11609-13.

28. Jacobs-Helber SM, Ryan JJ, Sawyer ST. JNK and p38 are activated by erythropoietin (EPO) but are not induced in apoptosis following EPO withdrawal in EPO-dependent HCD57 cells. Blood. 2000; 96:933-40

29. Yokomaku Y, Toshiro Sugimoto T, Shinji Kume S. et al. Asialoerythropoietin Prevents Contrast-Induced Nephropathy. J Am Soc Nephrol.2008; 19: 321328.

30. Csiszar A, Labinskyy N, Kira Smith K et al. Vasculoprotective Effects of Anti-Tumor Necrosis Factor- Treatment in Aging. American Journal of Pathology. 2007;170:388-698.

31. Hartmut Jaeschke H, Fisher M, Lawson $J$ et al. Activation of Caspase 3 (CPP32)-Like Proteases Is Essential for TNF- $\alpha$ Induced Hepatic Parenchymal Cell Apoptosis and NeutrophilMediated Necrosis in a Murine Endotoxin Shock Model. The Journal of Immunology 1998; 160: 3480-3486.

32. Gwinner W, Deters-Evers $U$, Brandes RP et al. Antioxidantoxidant balance in the glomerulus and proximal tubule of the rat kidney. J Physiol 1998; 509: 599606. 


\title{
تقييم تاثير هرمون الاريثروبوتثن على حماية الخلايا الكلوية من تدهور
}

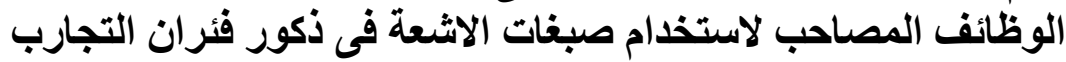

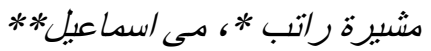

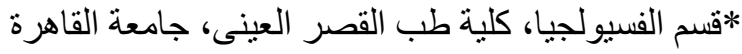

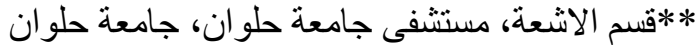

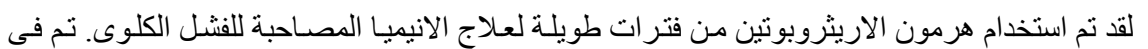

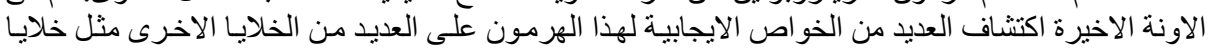

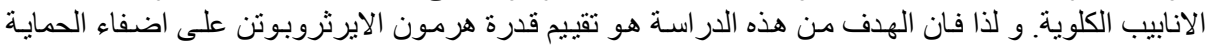

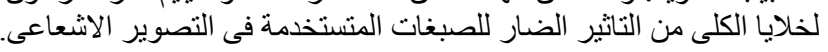

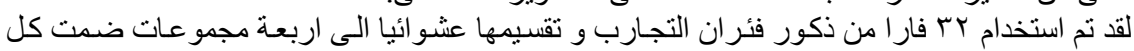

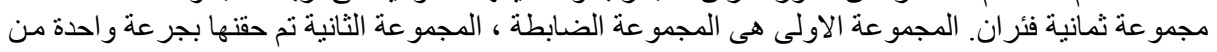

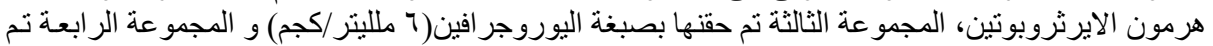

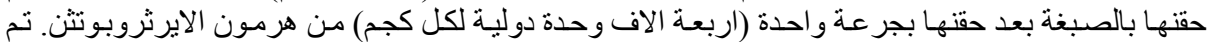

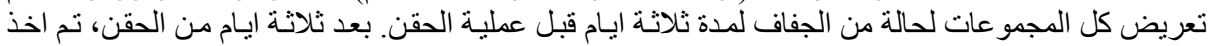

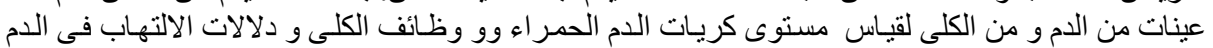

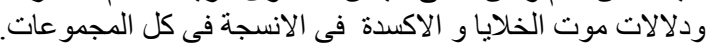

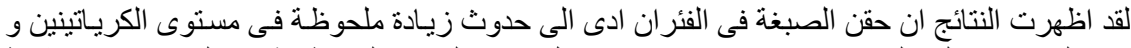

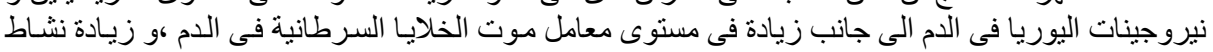

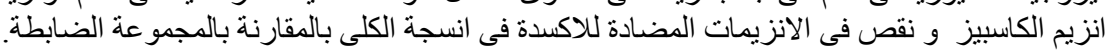

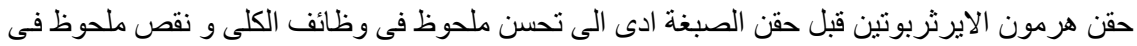

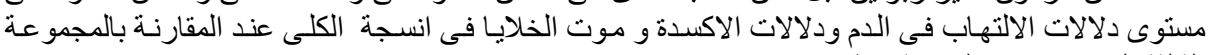
الثالثة التى تم حقنها بالصبغة فقط.

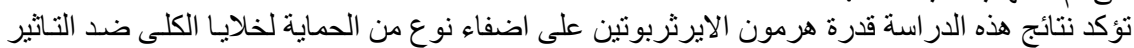

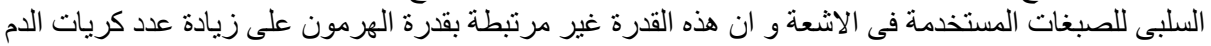
الحمراء 